\title{
A NEW CRETACEOUS RUDISTID FROM THE SAN FELIPE FORMATION OF MEXICO.
}

\author{
By Timothy W. Stanton, \\ Custodian of Mesozoic Invertebrate Fossils, United States National Museum.
}

The geology of the Tampico region in eastern Mexico is so important in its relation to the world's oil resources that any fact that will aid in classifying the rocks of that region more accurately is welcome. This fact as well as the interesting character of the fossil itself are excellent reasons for describing a single characteristic fossil which establishes the Cretaceous age of the San Felipe formation in its typical exposures west of Tampico. This formation, which overlies one of the chief oil-bearing horizons of the region, has yielded few determinable fossils. By correlation with fossiliferous beds at distant localities some geologists have referred it to the Cretaceous while other have considered it Eocene. The species herein described belongs to the family Radiolitidae, which, like the Hippuritidae, the only other family of the Rudistae, is strictly confined to Cretaceous rocks.

The fossil was presented to the United States National Museum by Mr. E. DeGolyer, chief geologist of the Compania Mexicana El Aguila, S. A., who furnished the following statement concerning the local geology:

The San Felipe is a formation consisting of 600 to 800 feet of alternating thin-bedded argillaceous limestone and shale known as the San Felipe beds. The limestones in the San Felipe are hardly ever more than 8 inches to 2 feet thick and the interbedded shales are quite similar. The limestones are much harder at the bottom of the section, becoming more and more argillaceous toward the top until where last seen they are really more bands of calcareous shale than limestone. The type locality lies between the stations of El Abra and Valles in the State of San Luis Potosi. The San Felipe beds are here exposed on the west flank of an asymmetrical anticline which brings up the Tamasopo limestone and forms the topographically prominent Sierra del Abra. The San Felipe is so called from a small ranch which lies 4 or 5 kilometers west of the El Abra station. The fossil was collected on the north side of the track at a point north $8^{\circ}$ west magnetic from the fourteenth telephone pole [about $\frac{1}{2}$ mile] east of Puente Diablo (Bridge of the Devil). The fossil was found in a hard blue limestone, weathering gray, overlain by 3 to 4 inches of limy yellow clay, and it in turn overlain by another thin limestone, all evidently belonging to the lower part of the San Felipe. Stratigraphically, I should say it was found at 80 to 100 feet above the base of the San Felipe. The formation where the fossil was collected strikes north $35^{\circ}$ west magnetic and shows a dip of $10^{\circ}$ to the southwest. 
The specific description, based on a single incomplete and somewhat weathered lower valve, is as follows:

SAUVAGESIA DEGOLYERI, new species.

Plates 96 and 97.

Lower valve large, elongate-conical, apparently slightly curved; shell thick, cellular, the cell walls forming a coarse reticulation in cross section, such as is characteristic of the genera Sauvagesia and Durania; cross section probably nearly circular when perfectly preserved but subelliptical in the type which shows evidence of some compression; internal ligamental ridge well developed, indicating reference to Sauvagesia rather than Durania; surface ornamented by about 20 to 25 moderately strong longitudinal costae which are apparently broader than the interspaces; siphonal bands not distinctly recognized on account of the weathered condition of the specimen.

Height of imperfect lower valve, $190 \mathrm{~mm}$; greater diameter at top, $95 \mathrm{~mm}$.; smaller diameter at top, $70 \mathrm{~mm}$.

Weathering has almost removed the costae so that their exact number and form are not determinable, but the bottoms of the grooves between the principal costae remain, and the weathering gives longitudinal sections of the costae showing the cells in each costa arranged in curved lines with the irregular concavity upward.

This species has a superficial resemblance to Barrettia monilifera Woodward, but the shell structure is totally different from that characteristic of the genus Barrettia. In size, form, general appearance, and minute shell structure Sauvagesia degolyeri is very much like an undescribed species of Sauvagesia in the United States Geological Survey collection from the upper part of the Brownstown marl near White Cliff, Arkansas. This suggests that the San Felipe formation may be on approximately the same horizon as the Brownstown marl; that is, within the zone of Exogyra ponderosa, but the evidence is not sufficient to justify making the positive correlation. It is certain, however, that the lower part of the San Felipe formation in which this Sauvagesia was collected is of Upper Cretaceous age.

Type-Cat. No. 32482 , U. S. N. M.

\section{EXPLANATION OF PLATES,}

Plate 96.

Sauvagesia degolyeri Stanton. Side view of type, slightly less than natural size. Cat. No. 32482 , U.S.N.M.

Plate 97.

Sauvagesia degolyeri Stanton. Cross section of type, slightly less than natura size. Cat. No. 32482 , U.S.N.M. 


\section{$2 \mathrm{BHL}$ Biodiversity Heritage Library}

Stanton, Timothy W. 1921. "A new Cretaceous rudistid from the San Felipe formation of Mexico." Proceedings of the United States National Museum 59(2379), 453-454. https://doi.org/10.5479/si.00963801.59-2379.453.

View This Item Online: https://www.biodiversitylibrary.org/item/32485

DOI: https://doi.org/10.5479/si.00963801.59-2379.453

Permalink: https://www.biodiversitylibrary.org/partpdf/18487

\section{Holding Institution}

Smithsonian Libraries

\section{Sponsored by}

Smithsonian

\section{Copyright \& Reuse}

Copyright Status: NOT_IN_COPYRIGHT

This document was created from content at the Biodiversity Heritage Library, the world's largest open access digital library for biodiversity literature and archives. Visit BHL at https://www.biodiversitylibrary.org. 